\title{
GENETICAL STUDIES ON SOME MORPHO-PHYSIOLOGICAL TRAITS IN SOME BREAD WHEAT CROSSES UNDER HEAT STRESS CONDITIONS
}

\author{
TAMMAM, A.M. AND A.G. ABD EL-RADY
}

Wheat Res. Department, Field Crops Res. Institute, ARC, Giza

(Manuscript received 24 January, 2010)

\begin{abstract}
This study was conducted at Shandaweel Agricultural Research Station, ARC Egypt, during the three growing seasons from 2003/04 to 2005/06. Six bread wheat genotypes namely Giza164, Giza164, Sids1, Sids7, Sahka 93 and Debeira were crossed in all possible combinations, excluding reciprocals. The parents, $F_{1}{ }^{\prime} s$ and $F_{2}{ }^{\prime} S$ generations were sown on favorable and late sowing dates to explore the genetic behavior of some agronomic characteristics, study the type of gene action controlling the agronomic traits and identify the best combination under heat stress (Late sowing).The results indicated that Late sowing reduced plant height, spike length, days to heading and days to maturity by (13.61 and $7.07 \%),(6.33$ and 5.66 $\%),(8.26$ and $8.2 \%)$ and ( 9.8 and $8.9 \%)$ for $F_{1}$ and $F_{2}$ generations, respectively as compared with the recommended sowing. The earliest genotype in heading was $\left(P_{5}\right)$ Sids 7 under both sowing dates, while the most promising $F_{2}$ populations were $\left(P_{3} \times P_{6}\right)$ and $\left(P_{3} \times P_{5}\right)$ under recommended planting and $\left(P_{2} \times P_{5}\right)$ and $\left(P_{4} \times P_{5}\right)$ under late planting. The results indicated that both additive and non-additive gene effects controlled the genetic system of plant height $(\mathrm{cm})$, spike length $(\mathrm{cm})$, days to heading and days to maturity. The additive gene effects were the most prevalent type under both sowing dates. The positive and negative alleles were unequally distributed among the parents for all traits under the two planting dates. The parents had more positive alleles for all traits in both generations under both sowing dates except in the $F_{1}$ hybrids under late sowing for heading date and in $F_{1}$ and $F_{2}$ generations under late sowing for maturity date which exhibited more negative alleles. Heritability values were high in both broad and narrow-sense for these characters. The previous results revealed that selection could be effective for developing these traits in segregating generations.
\end{abstract}

\section{INTRODUCTION}

Wheat crop is considered as one of the essential strategic cereal crops not only in Egypt but also all over the world since it is a staple food for humans. Heat stress is a major limitation to wheat (Triticum aestivum L.) productivity in arid, semiarid, tropical, and subtropical regions of the world (Fisher, 1986). Consequently development of heat-tolerant cultivars is a major concern in wheat breading programs. A detailed understanding of the genetics and physiology of tolerance as well as the use of the proper germplasm and selection methods will facilitate the 
development of heat tolerant cultivars of wheat. The most obvious effect of high temperature on wheat growth is the acceleration of plant development and subsequent overall reduction in the plant size (Midmore et al., 1984) Yield in stress environments is dependent upon stress susceptibility of a plant genotypes to stress which is the product of many physiological and morphological characters for which effective selection criteria have not yet been developed. Radmehr et al. (1996) indicated that high temperature following the January sowings accelerated the growth and development of plants, but shortened the duration of other development stages and resulted in a decrease in plant height. Selim (2000) found significant decrease in period to heading, period to maturity and main spike length as a result of delaying sowing date in both two growing seasons. Gribkova and Koretskaya (1985) and Kheiralla and Sheriff (1992) showed that the deleterious effects of high temperature were particularly high at heading dates. Singh et al. (1997) showed that the increase in temperature significantly reduced number of days to maturity. EL-Haddad (1975) and Hamada (2003) indicated that additive gene effects were higher than dominance gene effects in the expression of heading date and plant height. The average degree of dominance was less than one for both traits. The ratio $\mathrm{H}_{2} / 4 \mathrm{H}_{1}$ was 0.20 for both traits. The narrow-sense heritability estimate was $64.3 \%$ for both traits. Hassan et al. (1993), Nayeem and Veer (1998) and Tammam (2005) showed that additive and nonadditive gene effects were controlling the genetic system of heading date, plant height, spike length and days to maturity. Hamada (2003) and Tammam (2005) found that values of heritability (broad and narrow sense) for heading date, plant height and spike length were varied from high to moderate.

\section{The objectives of this study were:}

1-To study the genetic behavior of some agronomic characteristics in some bread wheat crosses under heat environments.

2-Study the type of gene action which controlling the morphophsiological traits under heat stress.

3-Identify the best combination under heat stress.

\section{MATERIALS AND METHODS}

This study was conducted at Shandaweel Agricultural Research Station, ARC, Egypt during the three growing seasons 2003/04, 2004/05 and 2005/06. The genetical materials chosen to be used in this study as parents included six bread wheat cultivars, which represents a wide range of diversity for several traits. The local name, pedigree and origin of these six varieties are presented in Table (1). 
Table 1. Local name, pedigree and origin of the six parents.

\begin{tabular}{|c|l|l|c|}
\hline $\begin{array}{c}\text { Ent. } \\
\text { No }\end{array}$ & \multicolumn{1}{|c|}{ Name } & \multicolumn{1}{|c|}{ Pedigree } & Origin \\
\hline 1 & Giza 164 & KVZ / BUHO"S" // KAl / BB=VEERY"S" \#5 & Egypt \\
\hline 2 & Giza 168 & MRL / BUC // SERI. & Egypt \\
\hline 3 & Sakha 93 & SAKHA 92 / TR 810328 & Egypt \\
\hline 4 & Sids 1 & HD21 / PAVON "S" // 1158.57 / MAYA74"S" & Egypt \\
\hline 5 & Sids 7 & IMAYA"S"/MON"S"//CMH74.592/3/SAKHA8*2 & Egypt \\
\hline 6 & Debeira & (Shandaweel Bread wheat breeding program) & Sudan \\
\hline
\end{tabular}

In 2003/04 season, grains of each of the parental varieties were sown at 3 various dates in order to produce grains of all possible cross combinations (excluding reciprocals) of the 6-parent diallel. In 2004/05 growing season, ten grains of each of the $15 F_{1}$ hybrids and the parents were sown in the field in one row spaced $30 \mathrm{~cm}$ apart and $10 \mathrm{~cm}$ between plants within rows to produce grains of the $F_{2}$ generation. In addition to, the parents were intercrossed again to produce more hybrid grains for each cross. In the season of 2005/06, the parents, the $F_{1}$ hybrids and $F_{2}$ populations were grown in two sowing dates namely, $25^{\text {th }}$ November (normal sowing date) and $25^{\text {th }}$ December (late sowing date).

The experiment was designed in a Randomized Complete Block Design with three replications. Each of the parents and $F_{1}$ hybrids were represented by one row, while each $F_{2}$ population was represented by six rows per block. The plants were grown in one-meter long rows, spaced $30 \mathrm{~cm}$. apart and plants spaced $10 \mathrm{~cm}$. within each row. The borders were sown with Sohag3 durum variety. The recommended agricultural practices were applied from sowing to harvest.

The following characteristics were measured on a random sample of 5 guarded plants from the parents, $F_{1}$ hybrids and mean random sample of 48 guarded plants from the $F_{2}$ populations in each replicate in the two planting dates. The means of the 5 or 48 plants were subjected to statistical and genetical analysis. The studied characters were plant height $(\mathrm{cm})$, spike length $(\mathrm{cm})$, days to heading and days to maturity. A diallel analysis as developed by Hayman (1954 a, b, 1957 and 1958) and Mather and Jinks (1971) was performed on the data of 2005/06 season. 


\section{RESULTS AND DISCUSSION}

\section{1- Plant height (cm):}

The mean plant height for six parents, $15 F_{1}$ crosses and $15 F_{2}$ populations are presented in Table (2). The results revealed that the average of plant height for the parents ranged from $88.53 \mathrm{~cm}$ for Sids $7\left(\mathrm{P}_{5}\right)$ to $119.33 \mathrm{~cm}$ for Giza164 $\left(\mathrm{P}_{1}\right)$ with an average of $101.59 \mathrm{~cm}$ under recommended planting and varied from $73.87 \mathrm{~cm}$ for Sakha93 (P3) to $100.2 \mathrm{~cm}$ for Giza164 $\left(\mathrm{P}_{1}\right)$ with an average of $87.41 \mathrm{~cm}$ under late planting. The mean plant height for $F_{1}$ hybrids ranged from $95.13 \mathrm{~cm}$ for (Giza $168 \times$ Sakha 93) to $119.0 \mathrm{~cm}$ for (Giza $164 \times$ Sids 1) with a 3 verage of $106.32 \mathrm{~cm}$ under recommended planting and varied from $81.57 \mathrm{~cm}$ for (Giza $168 \times$ Sids 7) to 100.23 $\mathrm{cm}$ (Sids $1 \times$ Sids 7) with an average of $91.85 \mathrm{~cm}$ under late planting. The average of plant height for $F_{2}$ populations ranged from $93.73 \mathrm{~cm}$ for (Giza $168 \times$ Sakha 93) to $118.10 \mathrm{~cm}$ for (Giza $164 \times$ Sides 1) with an average of $105.03 \mathrm{~cm}$ under recommended planting and varied from $86.99 \mathrm{~cm}$. for (Giza $168 \times$ Sakha93) to 105.34 $\mathrm{cm}$. for (Giza $164 \times$ Sids 1) with an average of $97.60 \mathrm{~cm}$ under late planting. It was cleared that delaying in sowing reduced the mean plant height by 14.0, 13.61 and $7.07 \%$ for parents, $F_{1}$ and $F_{2}$ generations, respectively, when compared with the recommended date. Similar results were obtained by Radmehr et al. (1996).

\section{2- Spike length (cm):}

The mean spike length for the six parents and their $15 F_{1}$ crosses and $15 F_{2}$ populations are presented in Table (2). The results showed that the average of spike length for the parents ranged from $12.70 \mathrm{~cm}$ for Giza $164\left(P_{1}\right)$ to $19.43 \mathrm{~cm}$ for Sids 7 $\left(P_{5}\right)$ with an average of $14.82 \mathrm{~cm}$ under recommended planting and varied from 12.23 for Giza $164\left(P_{1}\right)$ to $17.33 \mathrm{~cm}$ for Sids $7\left(P_{5}\right)$ with an average of $14.00 \mathrm{~cm}$ under late planting. The average of the $F_{1}$ hybrids ranged from $12.60 \mathrm{~cm}$ for (Giza $164 \times$ Sakha 93) to $17.63 \mathrm{~cm}$ for (Sides $1 \times$ Sides 7) with an average of $15.03 \mathrm{~cm}$ under normal planting date and varied from $12.43 \mathrm{~cm}$ for (Giza $164 \times$ Sakha 93) to $15.80 \mathrm{~cm}$ for (Sides $1 \times$ Sides 7) with an average of $13.92 \mathrm{~cm}$ under late sowing date. For $F_{2}$ populations the average of spike length ranged from $13.43 \mathrm{~cm}$ for (Giza $164 \times$ Sakha 93) to $18.00 \mathrm{~cm}$. for (Sides $1 \times$ Sides 7) with an average of $14.86 \mathrm{~cm}$ under recommended planting, while it varied from $12.47 \mathrm{~cm}$ for (Giza $164 \times$ Sakha 93) to $16.90 \mathrm{~cm}$ for (Sides $1 \times$ Sides 7) with an average of $14.16 \mathrm{~cm}$ under late planting date, indicated that the reduction due to heat stress were $5.53,6.33$ and $5.66 \%$ for parents, $F_{1}$ and $F_{2}$ generations, respectively. These results are in agreement with those obtained by Selim (2000). 


\section{3- Days to heading:}

The average of days to $50 \%$ heading for the six parents and their $15 F_{1}$ hybrids and $15 \mathrm{~F}_{2}$ populations are presented in Table (2). The results exhibited that the average of days to $50 \%$ heading for the parents ranged from 82.33 for Sids $7\left(P_{5}\right)$ to 100.00 for Giza $164\left(\mathrm{P}_{1}\right)$ days with an average of 91.78 days under recommended sowing and varied from 80.33 for Sids7 $\left(P_{5}\right)$ to 91.33 for Giza $164\left(P_{1}\right)$ days with an average of 86.00 days under late sowing. The average of days to heading for $F_{1}$ hybrids ranged from 86.67 for (Sakha93x Sids7) to 98.33 for (Sids1 $x$ Debeira) with an average of 92.8 days under recommended sowing and varied from 81.00 for (Giza $168 \times$ Sids 7) to 90.00 for (Sids $1 \times$ Debeira) with an average of 85.13 days under late sowing.

Table 2. Mean performance of 6-parents genotypes, $F_{1}$ 's hybrids and $F_{2}$ 's Populations of wheat for Plant height, spike length, days to heading and days to maturity under normal $(\mathrm{N})$ and late $(\mathrm{L})$ sowing dates.

\begin{tabular}{|c|c|c|c|c|c|c|c|c|}
\hline \multirow{2}{*}{$\begin{array}{l}\text { Entry } \\
\text { Parents }\end{array}$} & \multicolumn{2}{|c|}{ Plant height $\mathrm{cm}$} & \multicolumn{2}{|c|}{ Spike length $\mathrm{cm}$} & \multicolumn{2}{|c|}{ Days to heading } & \multicolumn{2}{|c|}{ Days to maturity } \\
\hline & $\mathrm{N}$ & $\mathrm{L}$ & $\mathrm{N}$ & L & $\mathrm{N}$ & $\mathrm{L}$ & $\mathrm{N}$ & $\mathrm{L}$ \\
\hline$P_{1}$ & 119.33 & 100.2 & 12.70 & 12.23 & 100.00 & 91.33 & 142.67 & 130.33 \\
\hline $\mathrm{P}_{2}$ & 99.60 & 84.1 & 14.30 & 13.33 & 90.67 & 84.67 & 140.33 & 130.00 \\
\hline $\mathrm{P}_{3}$ & 89.80 & 73.87 & 13.63 & 13.43 & 90.00 & 85.00 & 145.67 & 129.00 \\
\hline $\mathrm{P}_{4}$ & 111.87 & 94.67 & 13.80 & 13.67 & 93.67 & 87.67 & 142.67 & 130.33 \\
\hline$P_{5}$ & 88.53 & 82.1 & 19.43 & 17.33 & 82.33 & 80.33 & 135.33 & 126.00 \\
\hline $\mathrm{P}_{6}$ & 100.40 & 89.53 & 15.03 & 14.00 & 94.00 & 87.00 & 145.67 & 129.33 \\
\hline Mean & $\begin{array}{c}101.59 * \\
*\end{array}$ & 87.41 & $14.82 \mathrm{~ns}$ & 14.00 & $91.78 * *$ & 86.00 & $142.06^{* *}$ & 129.17 \\
\hline $\begin{array}{l}\mathrm{LSD}(\mathrm{G}) \\
\mathrm{P} \leq 0.05\end{array}$ & 2.78 & 5.66 & 1.85 & 0.80 & 2.17 & 1.33 & 3.07 & 3.24 \\
\hline \multicolumn{9}{|l|}{$F_{1}$ hybrids } \\
\hline $\mathrm{P}_{1} \times \mathrm{P}_{2}$ & 105.53 & 95.33 & 14.53 & 14.10 & 93.33 & 87.67 & 145.00 & 131.00 \\
\hline$P_{1} \times P_{3}$ & 105.33 & 87.33 & 12.60 & 12.43 & 92.33 & 87.67 & 144.67 & 132.67 \\
\hline $\mathrm{P}_{1} \times \mathrm{P}_{4}$ & 119.0 & 93.9 & 14.80 & 13.90 & 94.67 & 87.33 & 145.67 & 129.00 \\
\hline $\mathrm{P}_{1} \times \mathrm{P}_{5}$ & 111.8 & 95.43 & 16.17 & 13.47 & 94.00 & 85.33 & 143.67 & 126.00 \\
\hline $\mathrm{P}_{1} \times \mathrm{P}_{6}$ & 112.13 & 92.43 & 15.13 & 14.00 & 94.33 & 87.33 & 144.00 & 128.67 \\
\hline$P_{2} \times P_{3}$ & 95.13 & 83.13 & 13.90 & 13.23 & 93.00 & 81.67 & 146.00 & 130.00 \\
\hline $\mathrm{P}_{2} \times \mathrm{P}_{4}$ & 109.8 & 93.53 & 14.97 & 14.90 & 93.33 & 86.67 & 145.33 & 130.67 \\
\hline$P_{2} \times P_{5}$ & 104.93 & 81.57 & 15.40 & 13.80 & 93.33 & 81.00 & 144.33 & 126.33 \\
\hline $\mathrm{P}_{2} \times \mathrm{P}_{6}$ & 101.73 & 95.9 & 14.80 & 14.47 & 93.67 & 86.00 & 146.67 & 132.00 \\
\hline $\mathrm{P}_{3} \times \mathrm{P}_{4}$ & 100.20 & 89.77 & 13.93 & 13.57 & 93.67 & 84.00 & 144.67 & 128.67 \\
\hline$P_{3} \times P_{5}$ & 101.0 & 88.1 & 14.47 & 13.00 & 86.67 & 82.33 & 135.33 & 126.67 \\
\hline $\mathrm{P}_{3} \times \mathrm{P}_{6}$ & 104.2 & 89.43 & 15.33 & 13.57 & 93.00 & 85.33 & 142.00 & 130.00 \\
\hline $\mathrm{P}_{4} \times \mathrm{P}_{5}$ & 110.93 & 100.23 & 17.63 & 15.80 & 89.33 & 82.67 & 138.00 & 127.67 \\
\hline $\mathrm{P}_{4} \times \mathrm{P}_{6}$ & 104.47 & 92.77 & 14.80 & 13.57 & 98.33 & 90.00 & 144.33 & 131.33 \\
\hline$P_{5} \times P_{6}$ & 108.6 & 98.9 & 16.93 & 15.00 & 89.00 & 82.00 & 138.33 & 126.33 \\
\hline Mean & $\begin{array}{c}106.32 * \\
*\end{array}$ & 91.85 & $15.03 *$ & 13.92 & $92.8 * *$ & 85.13 & $143.2 * *$ & 129.13 \\
\hline $\begin{array}{l}\text { LSD (G) } \\
P \leq 0.05\end{array}$ & 3.80 & 2.85 & 1.19 & 1.21 & 1.35 & 2.6 & 2.4 & 2.56 \\
\hline
\end{tabular}

\footnotetext{
$*, * *$ Significant at 0.05 and 0.01 levels of probability, respectively
} 
Table 2. continued

\begin{tabular}{|c|c|c|c|c|c|c|c|c|}
\hline Entry & \multicolumn{2}{|c|}{ Plant height $\mathrm{cm}$} & \multicolumn{2}{|c|}{ Spike length $\mathrm{cm}$} & \multicolumn{2}{|c|}{ Days to heading } & \multicolumn{2}{|c|}{ Days to maturity } \\
\hline $\mathrm{F}_{2}$ populations & $\mathrm{N}$ & $\mathrm{L}$ & $\mathrm{N}$ & L & $\mathrm{N}$ & $\mathrm{L}$ & $\mathrm{N}$ & $\mathrm{L}$ \\
\hline $\mathrm{P}_{1} \times \mathrm{P}_{2}$ & 105.06 & 97.93 & 13.77 & 13.33 & 92.33 & 85.67 & 140.00 & 131.67 \\
\hline$P_{1} \times P_{3}$ & 101.18 & 94.92 & 13.43 & 12.47 & 92.33 & 85.67 & 140.33 & 129.33 \\
\hline $\mathrm{P}_{1} \times \mathrm{P}_{4}$ & 118.1 & 105.34 & 13.97 & 13.47 & 91.33 & 84.67 & 141.33 & 129.33 \\
\hline$P_{1} \times P_{5}$ & 107.71 & 100.65 & 15.37 & 14.33 & 92.67 & 85.33 & 139.00 & 126.67 \\
\hline $\mathrm{P}_{1} \times \mathrm{P}_{6}$ & 112.05 & 99.1 & 14.47 & 13.90 & 92.33 & 85.67 & 141.33 & 129.33 \\
\hline $\mathrm{P}_{2} \times \mathrm{P}_{3}$ & 93.73 & 86.99 & 13.97 & 13.10 & 90.67 & 81.67 & 144.67 & 131.33 \\
\hline $\mathrm{P}_{2} \times \mathrm{P}_{4}$ & 103.22 & 101.45 & 14.90 & 14.77 & 92.33 & 82.33 & 144.67 & 129.33 \\
\hline$P_{2} \times P_{5}$ & 103.67 & 101.18 & 16.13 & 16.00 & 89.00 & 79.33 & 139.67 & 127.00 \\
\hline $\mathrm{P}_{2} \times \mathrm{P}_{6}$ & 100.14 & 95.23 & 14.57 & 14.23 & 91.33 & 85.00 & 143.33 & 130.00 \\
\hline $\mathrm{P}_{3} \times \mathrm{P}_{4}$ & 99.76 & 99.17 & 15.23 & 14.13 & 90.00 & 82.00 & 142.67 & 128.67 \\
\hline$P_{3} \times P_{5}$ & 104.78 & 88.69 & 15.43 & 14.53 & 87.33 & 80.67 & 139.00 & 127.67 \\
\hline $\mathrm{P}_{3} \times \mathrm{P}_{6}$ & 110.57 & 95.15 & 14.47 & 14.00 & 85.33 & 83.33 & 144.00 & 131.67 \\
\hline $\mathrm{P}_{4} \times \mathrm{P}_{5}$ & 105.23 & 98.82 & 18.00 & 16.90 & 87.67 & 79.33 & 140.33 & 127.67 \\
\hline $\mathrm{P}_{4} \times \mathrm{P}_{6}$ & 107.8 & 97.60 & 15.10 & 14.20 & 95.67 & 86.67 & 146.33 & 131.33 \\
\hline $\mathrm{P}_{5} \times \mathrm{P}_{6}$ & 102.43 & 101.69 & 14.10 & 13.10 & 92.33 & 83.33 & 144.00 & 130.33 \\
\hline Mean & $105.03 * *$ & 97.60 & $14.86 \mathrm{~ns}$ & 14.16 & $90.84 * *$ & 83.37 & $142.04 * *$ & 129.42 \\
\hline $\begin{array}{l}\text { LSD (G) } \\
P \leq 0.05\end{array}$ & 2.67 & 2.93 & 1.26 & 1.03 & 1.96 & 2.35 & 1.99 & 2.29 \\
\hline
\end{tabular}

LSD $(G)=$ Genotypes.

$*, * *$ Significant at 0.05 and 0.01 levels of probability, respectively

The average of $F_{2}$ populations, ranged from 85.33 for (Sakha $93 \times$ Debeira) to 95.67 for (Sids $1 \times$ Debeira) with an average of 90.84 days under recommended planting date, while it ranged from 79.33 for both (Giza $168 \times$ Sids 7) and (Sids $1 \times$ Sids 7) to 86.67 for (Sids $1 \times$ Debeira) with an average of 83.37 under late planting date, indicated that a $6.29,8.26$ and $8.2 \%$ dedication due to heat stress for parents, $F_{1}$ and $F_{2}$ generations, respectively. These results could be due to the fact that heat units and the accumulated metabolites required for wheat flowering were reduced in the late planting. Kheiralla and Sheriff (1992) found that late sowing decreased time to heading date. Similar results were obtained by Gribkova and Koretskaya (1985) and Selim (2000). 


\section{4- Days to maturity:}

The average of number of days to maturity for the six parents and their $15 F_{1}$ hybrids and $15 \mathrm{~F}_{2}$ populations are presented in Table (2). The results revealed that the average of days to maturity for the parents ranged from 135.33 days for Sids7 $\left(P_{5}\right)$ to 145.67 days for both Sakha93 $\left(P_{3}\right)$ and Debeira $\left(P_{6}\right)$ with an average of 142.06 days under recommended planting and varied from 126.00 days for Sids7 $\left(P_{5}\right)$ to 130.33 days for both Giza $164\left(\mathrm{P}_{1}\right)$ and Sids $1\left(\mathrm{P}_{4}\right)$ with an average of 129.17 days under late planting. The average of days to maturity for $F_{1}$ hybrids ranged from 135.33 days for (Sakha93x Sids7) to 146.67 days for (Giza168x Debeira) with an average of 143.2 days under recommended sowing and varied from 126.00 days for (Giza164 x Sids 7) to 132.67 days for (Giza 164 x Sakha93) with an average of 129.13 days under late planting date. For $F_{2}$ populations, it ranged from 139.00 days for both (Giza164x Sids7) and (Sakha93x Sids7) to 146.33 days for (Sids1x Debeira) with an average of 142.04 days under recommended planting, while it varied from 126.67 days for (Giza164x Sids7) to 131.67 days for both (Giza164 x Giza168) and (Sakha93x Debeira) with an average of 129.42 days under late planting. These results showed that delayed planting reduced number of days to maturity by $9.07,9.8$ and $8.9 \%$ for parents, $F_{1}$ and $F_{2}$ generations, respectively, when compared with the recommended planting. These results are in line with those obtained by Singh et al. (1997) and Selim (2000).

\section{Genetic analysis:}

The diallel analysis of variance for plant height, spike length, days to heading and days to maturity in the $F_{1}$ and $F_{2}$ generations are given in Table (3). Data showed significant mean squares of additive "a" and non-additive "b" items for all studied traits in the $F_{1}$ and $F_{2}$ generations under two sowing dates, indicating the additive and dominance gene effects were involved in the genetic system controlling these traits. The magnitude of additive genetic effect was very high when compared with nonadditive gene effects in both $F_{1}$ and $F_{2}$ generations under both environments. These results indicated that the additive gene action was the most important in the genetic system controlling these traits. The $b$ component was further partitioned to its separate components, $b_{1}, b_{2}$ and $b_{3}$. Direction of dominance $\left(b_{1}\right)$ was significant for all traits, except for spike length in both $F_{1}$ and $F_{2}$ generations under both environments, days to heading in the $F_{1}$ hybrids under late sowing date and days to maturity in $F_{1}$ hybrids under late sowing date and in the $F_{2}$ populations under both sowing dates, indicating the usefulness of these genotypes to be considered in breeding program aims for producing high yielding varieties. The $b_{2}$ was highly significant for all traits, except for days to heading in the $F_{1}$ hybrids under late sowing date and days to 
maturity in both $F_{1}$ and $F_{2}$ generations under late sowing date, suggesting that the distributions of dominant and recessive alleles were unequal between the parents. Also $b_{3}$ was highly significant and significant for all traits in both $F_{1}$ and $F_{2}$ generations under both environments, demonstrating the superiority of some specific combinations and /or epistasis. Similar findings were obtained by El-Hadad (1975), Hassan et al. (1993), Nayeem and Veer (1998), Hamada (2003) and Tammam (2005).

\section{Graphical analysis:}

The analysis of variance of $(\mathrm{Wr}+\mathrm{Vr})$ and $(\mathrm{Wr}-\mathrm{Vr})$ values for $F_{1}$ and $F_{2}$ generations are presented in Table (4).The differences between arrays of the $(\mathrm{Wr}+\mathrm{Vr})$ values were highly significant for all traits except for spike length in the $F_{1}$ hybrids under normal sowing date, days to heading in the $F_{1}$ hybrids under late sowing date and days to maturity in the $F_{2}$ populations under the two sowing dates, indicating the presence of non-additive gene effects in the inheritance of these traits. While the insignificance of the $(\mathrm{Wr}+\mathrm{Vr})$ values, confirming that the additive-dominance model adequated for genetic system controlling these traits. The analysis of variance for (Wr-Vr) showed significant difference between arrays for plant height in the $F_{1}$ hybrids under late sowing and in the $F_{2}$ populations under the two planting dates and for days to heading in both $F_{1}$ and $F_{2}$ generations under normal planting date, confirming that apart of the non-additive gene effect may be due to epistatic effects. On the other hand it was insignificant in both $F_{1}$ and $F_{2}$ generations under both sowing dates for spike length except in the $F_{2}$ populations under late sowing and for days to maturity except in the $F_{1}$ hybrids under normal planting date, suggesting the absence of deviation of the additive-dominance model.

The $\mathrm{Wr} / \mathrm{Vr}$ graphs for the studied traits for both $F_{1}$ and $F_{2}$ generations are shown in Figures $(1-8)$. The regression coefficients were significant from zero and not from unity for plant height in the $F_{1}$ hybrids under two sowing dates and in $F_{2}$ populations under late sowing, spike length in both $F_{1}$ and $F_{2}$ generations under two sowing dates, days to heading in the $F_{1}$ under recommended planting and in the $F_{2}$ populations under late sowing and days to maturity in $F_{2}$ populations under the two planting dates, indicating that additive-dominance model is adequate for describing the variation in these traits under these conditions. These results were confirmed with those results of EL-Haddad (1975) and Hamada (2003). 
Table 3.The diallel analysis of variance for plant height, spike length, days to heading and days to maturity of 6 parents of wheat genotypes, in $F_{1}$ hybrids and in $\mathrm{F}_{2}$ Populations under normal $(\mathrm{N})$ and late $(\mathrm{L})$ planting dates.

\begin{tabular}{|c|c|c|c|c|c|c|c|c|c|}
\hline Item & d.f & \multicolumn{2}{|c|}{ Plant height } & \multicolumn{2}{|c|}{ Spike length } & \multicolumn{2}{|c|}{ Days to heading } & \multicolumn{2}{|c|}{ Days to maturity } \\
\hline$F_{1}$ hybrids & & $\mathrm{N}$ & L & $\mathrm{N}$ & L & $\mathrm{N}$ & L & $\mathrm{N}$ & L \\
\hline$a$ & 5 & $772.8^{* *}$ & $440.95^{* *}$ & $32.67 * *$ & $11.68^{* *}$ & $152.0^{* *}$ & $135.5^{* *}$ & $139.5^{* *}$ & $61.2^{* *}$ \\
\hline b & 15 & $106.48^{* *}$ & $119.79 * *$ & $3.28 * *$ & $3.18^{* *}$ & $26.18^{* *}$ & $10.41^{* *}$ & $32.03 * *$ & $9.17 *$ \\
\hline$b_{1}$ & 1 & $335.75^{* *}$ & $295.70 * *$ & 0.661 & 0.096 & $15.67 * *$ & 11.27 & $19.65^{*}$ & 0.0167 \\
\hline$b_{2}$ & 5 & $136.5^{* *}$ & $74.89 * *$ & $3.76 * *$ & $5.13 * *$ & $22.04 * *$ & 2.08 & $43.43^{* *}$ & 6.063 \\
\hline$b_{3}$ & 9 & $64.33 * *$ & $125.19 * *$ & $3.31 * *$ & $2.44 * *$ & $29.64 * *$ & $14.94 * *$ & $27.08^{* *}$ & $11.82 *$ \\
\hline Block interaction & 40 & 7.990 & 6.961 & 0.982 & 0.835 & 1.264 & 3.879 & 3.768 & 4.213 \\
\hline$F_{2}$ populations & & & & & & & & & \\
\hline$a$ & 5 & $666.55^{* *}$ & $473.43 * *$ & $26.62 * *$ & $19.51^{* *}$ & $124.1^{* *}$ & $114.9 * *$ & $96.8^{* *}$ & $32.8^{* *}$ \\
\hline b & 15 & $129.4^{* *}$ & $179.68^{* *}$ & $4.06 * *$ & $3.67 * *$ & $42.06^{* *}$ & $15.00^{* *}$ & $13.57 * *$ & $7.35^{*}$ \\
\hline $\mathrm{b}_{1}$ & 1 & $160.63 * *$ & $1606.6^{* *}$ & 0.0286 & 0.406 & $17.07 * *$ & $92.92 * *$ & 0.0185 & 0.979 \\
\hline$b_{2}$ & 5 & $139.49 * *$ & $54.42 * *$ & $4.99 * *$ & $2.57^{* *}$ & $35.45^{* *}$ & $8.17^{*}$ & $21.08^{* *}$ & 5.26 \\
\hline$b_{3}$ & 9 & $120.32 * *$ & $90.72 * *$ & $3.99 * *$ & $4.64 * *$ & $48.51 * *$ & $10.16^{* *}$ & $10.90 * *$ & $9.22 *$ \\
\hline Block interaction & 40 & 5.0266 & 7.553 & 1.0683 & 0.610 & 2.292 & 3.110 & 3.141 & 3.453 \\
\hline
\end{tabular}

\footnotetext{
*, ** Significant at 0.05 and 0.01 levels of probability, respectively.
} 
Table 4. Analysis of variance of the $(\mathrm{Wr}+\mathrm{Vr})$ and $(\mathrm{Wr}-\mathrm{Vr})$ values for plant height, spike length, days to heading and days to maturity in both $\mathrm{F}_{1}$ and $\mathrm{F}_{2}$ generations under normal $(\mathrm{N})$ and late $(\mathrm{L})$ planting.

\begin{tabular}{|c|c|c|c|c|c|c|c|c|c|}
\hline \multirow{3}{*}{$\begin{array}{l}\text { Item } \\
F_{1} \text { hybrids } \\
\end{array}$} & \multirow[t]{3}{*}{ d.f } & \multicolumn{4}{|c|}{ Plant height } & \multicolumn{4}{|c|}{ Spike length } \\
\hline & & \multicolumn{2}{|c|}{$\mathrm{N}$} & \multicolumn{2}{|c|}{$\mathrm{L}$} & \multicolumn{2}{|c|}{$\mathrm{N}$} & \multicolumn{2}{|c|}{$\mathrm{L}$} \\
\hline & & $\mathrm{Wr}+\mathrm{Vr}$ & $\mathrm{Wr}-\mathrm{Vr}$ & $\mathrm{Wr}+\mathrm{Vr}$ & $\mathrm{Wr}-\mathrm{Vr}$ & $\mathrm{Wr}+\mathrm{Vr}$ & Wr-Vr & $\mathrm{Wr}+\mathrm{Vr}$ & $\mathrm{Wr}-\mathrm{Vr}$ \\
\hline Blocks & 2 & 333.07 & 276.76 & 41.68 & 335.39 & 2.452 & 1.212 & 0.329 & 1.51 \\
\hline Arrays & 5 & $5772.5^{* *}$ & 168.35 & $6327.6 * *$ & $456.1 * *$ & 13.05 & 0.926 & $10.00 *$ & 0.469 \\
\hline Error & 10 & 678.87 & 113.22 & 721.82 & 46.94 & 7.365 & 0.972 & 2.849 & 2.03 \\
\hline \multicolumn{10}{|l|}{$F_{2}$ populations } \\
\hline Blocks & 2 & 220.43 & 32.86 & 268.40 & 173.35 & 0.714 & 4.141 & 4.68 & 0.422 \\
\hline Arrays & 5 & $3343.3 * *$ & $2026.1^{* *}$ & $10793.5 * *$ & $483.3^{* *}$ & $20.90 * *$ & 2.935 & $9.66 *$ & $2.06 * *$ \\
\hline Error & 10 & 593.18 & 28.51 & 1434.94 & 62.38 & 0.776 & 1.532 & 1.72 & 0.319 \\
\hline
\end{tabular}

\begin{tabular}{|c|c|c|c|c|c|c|c|c|c|}
\hline \multirow{3}{*}{\begin{tabular}{|l} 
\\
\\
\end{tabular}} & \multirow[t]{3}{*}{ d.f } & \multicolumn{4}{|c|}{ Days to heading } & \multicolumn{4}{|c|}{ Days to maturity } \\
\hline & & \multicolumn{2}{|c|}{$\mathrm{N}$} & \multicolumn{2}{|c|}{$\mathrm{L}$} & \multicolumn{2}{|c|}{$\mathrm{N}$} & \multicolumn{2}{|c|}{$\mathrm{L}$} \\
\hline & & $\mathrm{Wr}+\mathrm{Vr}$ & $\mathrm{Wr}-\mathrm{Vr}$ & $\mathrm{Wr}+\mathrm{Vr}$ & $\mathrm{Wr}-\mathrm{Vr}$ & $\mathrm{Wr}+\mathrm{Vr}$ & $\mathrm{Wr}-\mathrm{Vr}$ & $\mathrm{Wr}+\mathrm{Vr}$ & $\mathrm{Wr}-\mathrm{Vr}$ \\
\hline Blocks & 2 & 2.40 & 5.29 & 61.46 & .588 & 48.30 & 43.66 & 55.55 & 2.46 \\
\hline Arrays & 5 & $438.90 * *$ & $10.19^{*}$ & 28.18 & 7.389 & $234.6^{*}$ & $116.1^{* *}$ & $33.51 *$ & 4.78 \\
\hline Error & 10 & 36.67 & 2.65 & 32.19 & 5.734 & 51.78 & 12.417 & 6.788 & 2.227 \\
\hline \multicolumn{10}{|l|}{$\mathrm{F}_{2}$ populations } \\
\hline Blocks & 2 & 3.59 & 37.49 & 8.55 & 24.45 & 18.99 & 8.341 & 0.186 & 3.76 \\
\hline Arrays & 5 & $246.8 * *$ & $155.5^{* * *}$ & $58.72 *$ & 5.65 & 59.89 & 7.654 & 3.56 & 2.96 \\
\hline Error & 10 & 26.70 & 10.666 & 15.83 & 4.20 & 34.36 & 8.999 & 15.83 & 4.20 \\
\hline
\end{tabular}

$*, * *$ Significant at 0.05 and 0.01 levels of probability, respectively.
$\mathrm{N}$ : Normal planting.
$\mathrm{L}$ : Late planting 
Fig 1 
Fig 5 
Tables 5. Components of genetic variation influencing plant height, spike length, days to heading and days to maturity in both $F_{1}$ and $F_{2}$ generations under both normal $(\mathrm{N})$ and late $(\mathrm{L})$ planting dates.

\begin{tabular}{|c|c|c|c|c|c|c|c|c|}
\hline \multirow[t]{2}{*}{ Components } & \multicolumn{2}{|c|}{ Plant height } & \multicolumn{2}{|c|}{ Spike length } & \multicolumn{2}{|c|}{ Days to heading } & \multicolumn{2}{|c|}{ Days to maturity } \\
\hline & $\mathrm{N}$ & $\mathrm{L}$ & $\mathrm{N}$ & $L$ & $\mathrm{~N}$ & $L$ & $\mathrm{~N}$ & $\mathrm{~L}$ \\
\hline \multicolumn{9}{|l|}{$F_{1}$ hybrids } \\
\hline D & $\begin{array}{c}142.49 \pm \\
6.64 \\
\end{array}$ & $\begin{array}{c}84.69 \pm \\
4.27 \\
\end{array}$ & $\begin{array}{c}5.147 \pm \\
0.615 \\
\end{array}$ & $\begin{array}{c}2.54 \pm \\
0.21 \\
\end{array}$ & $\begin{array}{c}33.22 \pm \\
1.02\end{array}$ & $\begin{array}{c}11.21 \pm \\
1.49 \\
\end{array}$ & $\begin{array}{c}12.84 \pm \\
2.20 \\
\end{array}$ & $\begin{array}{c}0.295 \pm \\
.930 \\
\end{array}$ \\
\hline $\mathrm{F}$ & $\begin{array}{c}85.4 \pm \\
16.21 \\
\end{array}$ & $\begin{array}{c}51.02 \pm \\
10.44 \\
\end{array}$ & $\begin{array}{c}2.164 \pm \\
1.50 \\
\end{array}$ & $\begin{array}{c}2.27 \pm \\
0.761 \\
\end{array}$ & $\begin{array}{c}20.99 \pm \\
2.48\end{array}$ & $\begin{array}{c}-4.12 \pm \\
3.65 \\
\end{array}$ & $\begin{array}{c}6.28 \pm \\
5.37 \\
\end{array}$ & $\begin{array}{c}-5.96 \pm \\
2.27 \\
\end{array}$ \\
\hline $\mathrm{H}_{1}$ & $\begin{array}{l}89.1 \pm \\
16.84 \\
\end{array}$ & $\begin{array}{c}85.90 \\
\pm 10.85 \\
\end{array}$ & $\begin{array}{c}1.52 \pm \\
1.56 \\
\end{array}$ & $\begin{array}{c}1.99 \pm \\
0.761 \\
\end{array}$ & $\begin{array}{c}20.42 \\
\pm 2.58 \\
\end{array}$ & $\begin{array}{c}1.50 \pm \\
3.79 \\
\end{array}$ & $\begin{array}{c}25.25 \pm \\
5.58 \\
\end{array}$ & $\begin{array}{c}1.01 \pm \\
2.36 \\
\end{array}$ \\
\hline $\mathrm{H}_{2}$ & $\begin{array}{c}62.1 \pm \\
15.05 \\
\end{array}$ & $\begin{array}{c}72.14 \pm \\
9.69 \\
\end{array}$ & $\begin{array}{c}1.10 \pm \\
1.39 \\
\end{array}$ & $\begin{array}{c}1.19 \pm \\
0.680 \\
\end{array}$ & $\begin{array}{c}16.04 \pm \\
2.30\end{array}$ & $\begin{array}{c}2.63 \pm \\
3.39 \\
\end{array}$ & $\begin{array}{c}17.16 \\
\pm 4.98 \\
\end{array}$ & $\begin{array}{c}1.41 \pm \\
2.11 \\
\end{array}$ \\
\hline $\mathrm{h}_{2}$ & $\begin{array}{c}59.65 \pm \\
6.39\end{array}$ & $\begin{array}{c}52.53 \pm \\
6.52\end{array}$ & $\begin{array}{c}-0.189 \pm \\
0.94\end{array}$ & $\begin{array}{l}-0.247 \\
\pm 0.46\end{array}$ & $\begin{array}{c}2.49 \pm \\
1.55\end{array}$ & $\begin{array}{c}1.187 \pm \\
2.28\end{array}$ & $\begin{array}{c}2.445 \pm \\
3.351\end{array}$ & $\begin{array}{c}-1.33 \pm \\
1.419 \\
\end{array}$ \\
\hline E & $\begin{array}{c}4.57 \pm \\
2.51 \\
\end{array}$ & $\begin{array}{c}3.98 \pm \\
1.62 \\
\end{array}$ & $\begin{array}{c}0.561 \pm \\
0.232 \\
\end{array}$ & $\begin{array}{c}0.477 \pm \\
0.113\end{array}$ & $\begin{array}{c}0.723 \pm \\
.384\end{array}$ & $\begin{array}{c}2.215 \pm \\
0.564 \\
\end{array}$ & $\begin{array}{c}2.157 \pm \\
.831 \\
\end{array}$ & $\begin{array}{c}2.405 \pm \\
0.35\end{array}$ \\
\hline$\left(H_{1} / D\right)^{1 / 2}$ & 0.791 & 1.01 & 0.544 & 0.884 & 0.784 & 0.365 & 1.402 & 1.852 \\
\hline $\mathrm{H}_{2} / 4 \mathrm{H}_{1}$ uv & 0.174 & 0.210 & 0.179 & 0.149 & 0.196 & 0.439 & 0.169 & 0.349 \\
\hline $\begin{array}{l}\left(4 \mathrm{DH}_{1}\right)^{1 / 2}+\mathrm{F} / \\
\left(4 \mathrm{DH}_{1}\right)^{1 / 2}-\mathrm{F}\end{array}$ & 2.220 & 1.85 & 2.260 & 2.96 & 2.349 & 0.330 & 1.42 & -0.690 \\
\hline $\mathrm{h}_{2} / \mathrm{H}_{2}$ & 0.961 & 0.728 & -0.173 & -0.210 & 0.156 & 0.452 & 0.1425 & -0.946 \\
\hline $\mathrm{H}_{\text {b.s }}$ & $92.6 \%$ & $91.3 \%$ & $77.92 \%$ & $\begin{array}{c}64.14 \\
\% \\
\end{array}$ & $94.45 \%$ & $\begin{array}{c}77.78 \\
\% \\
\end{array}$ & $84.33 \%$ & $57.7 \%$ \\
\hline $\mathrm{H}_{\mathrm{n} . \mathrm{s}}$ & $67.6 \%$ & $51.8 \%$ & $67.14 \%$ & $\begin{array}{c}41.76 \\
\% \\
\end{array}$ & $63.69 \%$ & $\begin{array}{c}71.19 \\
\% \\
\end{array}$ & $53.18 \%$ & $51.51 \%$ \\
\hline \multicolumn{9}{|l|}{$\mathrm{F}_{2}$ populations } \\
\hline D & $\begin{array}{r}144.19 \\
\pm 3.33 \\
\end{array}$ & $\begin{array}{c}84.35 \pm \\
4.93 \\
\end{array}$ & $\begin{array}{c}5.097 \pm \\
.772 \\
\end{array}$ & $\begin{array}{c}2.67 \pm \\
0.352 \\
\end{array}$ & $\begin{array}{c}32.63 \pm \\
2.04 \\
\end{array}$ & $\begin{array}{c}11.65 \\
\pm 1.28 \\
\end{array}$ & $\begin{array}{r}13.20 \\
\pm 1.87 \\
\end{array}$ & $\begin{array}{c}0.727 \pm \\
0.762 \\
\end{array}$ \\
\hline $\mathrm{F}$ & $\begin{array}{l}200.33 \\
\pm 8.13 \\
\end{array}$ & $\begin{array}{c}84.80 \pm \\
12.03 \\
\end{array}$ & $\begin{array}{c}6.092 \pm \\
1.885 \\
\end{array}$ & $\begin{array}{c}1.92 \pm \\
0.861 \\
\end{array}$ & $\begin{array}{c}52.56 \pm \\
4.98 \\
\end{array}$ & $\begin{array}{c}0.212 \\
\pm 3.12 \\
\end{array}$ & $\begin{array}{c}13.07 \pm \\
4.57 \\
\end{array}$ & $\begin{array}{c}-4.82 \pm \\
1.86 \\
\end{array}$ \\
\hline $\mathrm{H}_{1}$ & $\begin{array}{l}463.95 \\
\pm 8.45 \\
\end{array}$ & $\begin{array}{c}519.81 \pm \\
12.5 \\
\end{array}$ & $\begin{array}{c}14.184 \pm \\
1.96 \\
\end{array}$ & $\begin{array}{c}11.45 \pm \\
0.895 \\
\end{array}$ & $\begin{array}{c}141.34 \pm \\
5.17 \\
\end{array}$ & $\begin{array}{c}44.12 \\
\pm 3.24 \\
\end{array}$ & $\begin{array}{c}51.72 \pm \\
4.75 \\
\end{array}$ & $\begin{array}{l}20.72 \\
\pm 1.94 \\
\end{array}$ \\
\hline $\mathrm{H}_{2}$ & $\begin{array}{l}322.72 \\
\pm 7.55 \\
\end{array}$ & $\begin{array}{c}445.6 \pm \\
11.17 \\
\end{array}$ & $\begin{array}{c}6.08 \pm \\
1.750 \\
\end{array}$ & $\begin{array}{c}7.07 \pm \\
0.799 \\
\end{array}$ & $\begin{array}{c}101.97 \pm \\
4.62 \\
\end{array}$ & $\begin{array}{c}26.19 \pm \\
2.90 \\
\end{array}$ & $\begin{array}{c}22.12 \pm \\
4.24 \\
\end{array}$ & $\begin{array}{c}4.11 \pm \\
1.73 \\
\end{array}$ \\
\hline $\mathrm{h}_{2}$ & $\begin{array}{c}80.28 \pm \\
20.32 \\
\end{array}$ & $\begin{array}{c}20.68 \pm \\
30.66 \\
\end{array}$ & $\begin{array}{c}-8.12 \pm \\
4.71\end{array}$ & $\begin{array}{c}-4.23 \pm \\
2.15 \\
\end{array}$ & $\begin{array}{c}-4.8 \pm \\
12.43 \\
\end{array}$ & $\begin{array}{c}45.15 \pm \\
7.81 \\
\end{array}$ & $\begin{array}{c}-23.9 \pm \\
11.42 \\
\end{array}$ & $\begin{array}{c}-25.37 \pm \\
4.65\end{array}$ \\
\hline E & $\begin{array}{c}2.87 \pm \\
1.26\end{array}$ & $\begin{array}{c}4.32 \pm \\
1.86\end{array}$ & $\begin{array}{c}0.611 \pm \\
0.292\end{array}$ & $\begin{array}{l}0.348 \\
\pm \quad 0.13 \\
\end{array}$ & $\begin{array}{c}1.31 \pm \\
0.769\end{array}$ & $\begin{array}{c}1.776 \pm \\
0.483\end{array}$ & $\begin{array}{c}1.79 \pm \\
.707\end{array}$ & $\begin{array}{c}1.97 \pm \\
0.288\end{array}$ \\
\hline$\left(H_{1} / D\right)^{1 / 2}$ & 0.897 & 1.24 & 0.834 & 1.034 & 1.041 & 0.973 & 0.989 & 2.669 \\
\hline $\mathrm{H}_{2} / 4 \mathrm{H}_{1}$ uv & 0.174 & 0.214 & 0.107 & 0.154 & 0.180 & 0.148 & 0.107 & 0.0497 \\
\hline $\begin{array}{l}\left(4 \mathrm{DH}_{1}\right)^{1 / 2}+\mathrm{F} / \\
\left(4 \mathrm{DH}_{1}\right)^{1 / 2}-\mathrm{F}\end{array}$ & 2.264 & 1.5 & 2.163 & 1.42 & 2.263 & 1.01 & 1.67 & 0.234 \\
\hline $\mathrm{h}_{2} / \mathrm{H}_{2}$ & 0.250 & 0.046 & -1.34 & -1.58 & -.047 & 1.72 & -1.08 & -6.16 \\
\hline $\mathrm{H}_{\text {b.s }}$ & $95.4 \%$ & $93.0 \%$ & $79.83 \%$ & $\begin{array}{c}84.12 \\
\% \\
\end{array}$ & $91.70 \%$ & $\begin{array}{c}84.42 \\
\% \\
\end{array}$ & $82.47 \%$ & $66.38 \%$ \\
\hline $\mathrm{H}_{\mathrm{n} \cdot \mathrm{s}}$ & $63.2 \%$ & $48.4 \%$ & $67.30 \%$ & $\begin{array}{c}63.96 \\
\% \\
\end{array}$ & $51.30 \%$ & $\begin{array}{c}70.13 \\
\% \\
\end{array}$ & $68.89 \%$ & $62.03 \%$ \\
\hline
\end{tabular}




\section{The genetic components:}

The estimates of genetic component controlling the variation of the studied traits with their respective standard errors are presented in Table (5). The magnitude of additive gene effects "D" were significant for all studies traits in both $F_{1}$ and $F_{2}$ generations under the two planting dates except days to maturity in the $F_{2}$ populations under late planting. The dominance $\left(\mathrm{H}_{1}\right.$ and $\left.\mathrm{H}_{2}\right)$ components were significant for all studies traits in both $F_{1}$ and $F_{2}$ generations under the two planting dates except spike length in the $F_{1}$ hybrids under sowing dates, days to heading and days to maturity in the $F_{1}$ hybrids under late sowing date. The additives gene effects "D" were higher in magnitude than dominance fo- ${ }_{9}^{-1}$ studies traits in the $F_{1}$ hybrids under the two sowing dates, indicating that additives gene effects play an important role in the expression for these traits. Similar findings were obtained by El-Hadad (1975), Hassan et al. (1993) and Hamada (2003). The average degree of dominance $\left(H_{1} / D\right)^{1 / 2}$ was less than unity for all studies traits except for plant height in both generations under late planting date, spike length in the $F_{2}$ populations under late planting, days to heading in the $F_{1}$ hybrids under normal sowing date and days to maturity in the $F_{1}$ hybrids under both sowing dates and in the $F_{2}$ populations under late planting date. These results confirm the presence of partial dominance. These results are in agreement with those reported by EL-Haddad (1975) and Hamada (2003).The estimates of $\mathrm{H}_{2} / 4 \mathrm{H}_{1}$ were less than 0.25 for all studies traits in both $\mathrm{F}_{1}$ and $F_{2}$ generations under recommended and late planting dates, indicated that unequal distribution of dominant to recessive genes between this group of parents. The ratio of $\left[\left(4 \mathrm{DH}_{1}\right)^{1 / 2}+\mathrm{F} /\left(4 \mathrm{DH}_{1}\right)^{1 / 2}-\mathrm{F}\right]$ was more than one in both generations under the two planting dates except for days to heading in the $F_{1}$ hybrids under late sowing date and days to maturity in both $F_{1}$ and $F_{2}$ generations under the late planting dates, indicated that the dominant genes were in excess.

Heritability values were high in both broad and narrow-sense for these traits except for harvest index in both $F_{1}$ and $F_{2}$ generations under the late planting dates, revealed that selection could be effective for developing these traits in segregating generations. These findings are in line with those reported by El-Haddad (1975).

\section{REFERENCES}

1. El-Haddad, M.M. 1975. Genetical analysis of diallel crosses in spring wheat, Egypt. J. Genet. Cytol. 4: 174-188.

2. Fisher, R.A. 1986. Physiological limitations to producing wheat in semitropical and tropical environments and possible. p-p 209-230. CIMMYT/ UNDP, Mexico. 
3. Gribkova,N.G and T.P. Koretskaya. 1985. The influence of high temperature on the growth, development and yield of winter wheat. Sbornik-Nauchnykh-Trudovpo-Prikladnoi-Botanike,-Genetike-i-Selektsii, 94: 62-67.

4. Hamada, A.A. 2003. Gene effects for some agronomic traits in three bread wheat crosses. Annals Agric. Sci., Ain Shams Univ., Cairo, 48(1): 131-146.

5. Hassan, A.A., M.S. Abdel- Sabour, A.Abdel-Shafi, H.S. Sherif and A.A. Hamada 1993. Genetical analysis of diallel crosses in bread wheat under different environmental conditions in Egypt. Egypt. J. Appl. Sci., 8(12): 1179-1197

6. Hayman, B.I. 1954a. The analysis of variance of diallel tables. Biometrics, 10:235244.

7. Hayman, B.I. 1954b. The theory and analysis of diallel crosses. Genetics, 39: 789-809.

8. Hayman, B.I. 1957. Interaction, heterosis and diallel crosses. Genetics, 42: 336355.

9. Hayman, B.I. 1958. The theory and analysis of diallel crosses. Genetics, 43: 6385.

10. Kheiralla, K.A. and T.H.I. Sherif . 1992. Inheritance of earliness and yield in wheat under heat stress. Assiut-Journal-of-Agricultural-Sciences. 23(1): 105-126.

11. Mather, K. and J.L. Jinks. 1971. Biometrical genetics ( $2^{\text {nd }}$ edition), Chapman and Hall, Ltd., London.

12. Midmore, D.J., P.M. Cartwright and R.A. Fisher. 1984. Wheat in tropical environments. II. Growth and grain yield. Field crops Res. 8: 207-227.

13. Nayeem, K.A and M.V. Veer. 1998. Gene effects for thermotolerance parameters and some yield components in bread wheat (Triticum aestivum L.) under normal and late sowing. Crop-Improvement. 25(2): 229-231.

14. Radmehr, M., G. Lotfali-Aeineh and A. Kajbaf. 1996.. Study on the effect of heat stress on agronomic traits, grain yield and yield components in twenty five bread wheat genotypes. Seed-and-Plant, 12(1): 13-23 (Pe), 3 (En).

15. Selim, Amal H. 2000. Evaluation of some heat tolerance wheat germplasms for yield and yield quality. Unpublished P.h.D Thesis, Agron. Dep., Fac. Of Agric., Ain shams Univ.,2000.

16. Singh, N.B., Ziauddin-Ahmad and Z. Ahmad. 1997. Response of wheat (Triticum aestivum) varieties to different dates of sowing. Indian-Journal-of-AgriculturalSciences, 67(5): 208-211.

17. Tammam, A.M. 2005. Generation mean analysis in bread wheat under different environmental conditions. Minufiy J. Agric. Res. 30 (3): 937-956. 


\title{
دراسات وراثية علي بعض الصفات المورفسيولوجية فى هن قمح الخبز تحت ظروف الحرارة
}

\author{
احد محمد تمام و السيد ، ايمن جمال عبد الر اضى
}

قسم بحوث القهح - معر المحاصبل الحقلية - مركز البحوث الزراعية - الجيزة

اجريت هذه الدراسة في محطة البحوث الزر اعية بشندويل محافظة سوهاج و التابعة لمركز

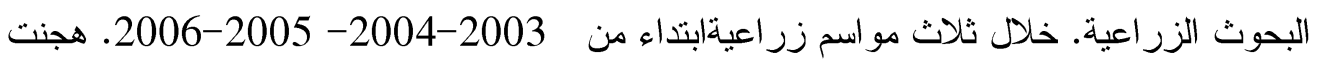

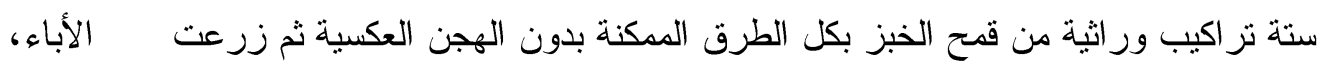

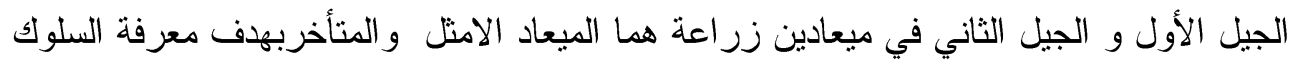

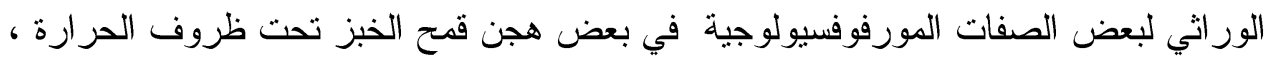

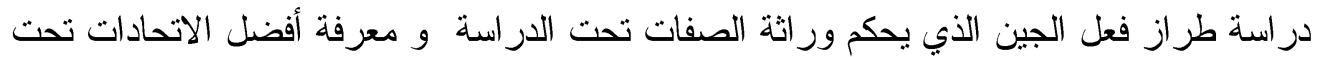
ظروف الحرارة. ادت الزر اعة المتأخرة الى خفض طول النبات، طول السنبلة، عدد الأيام حتى لهى التزهير وعدد الأيام حتى النضج بنسبة ( $13.61 ،$ \%) و (9.8، 8.9 \%) فى الجيل الأول و الجيل الثانى على التو الى عند المقارنة بالزر اعة في الميعاد

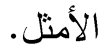

كان الصنف Sids 7 اكثر التز اكيب الور اثية تبكبر ا فى التزهير فى كلا ميعادي الزر اعة بينما كانت

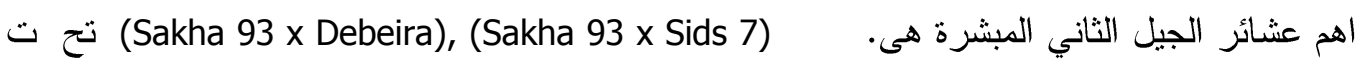

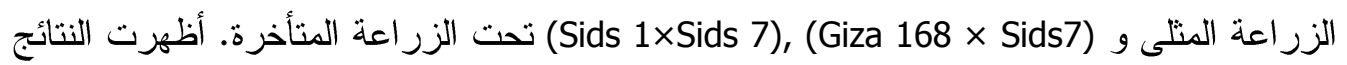
أن كلا من الفعل الإضافى و الفعل الغير إضافى للجين تتحكم فى النظام الور اثى للصفات طول النبات، طول السنبلة، تاريخ التزهير ، تاريخ النضج وكانت الجينات المضيفة اكثر اهية من الجينات الغير

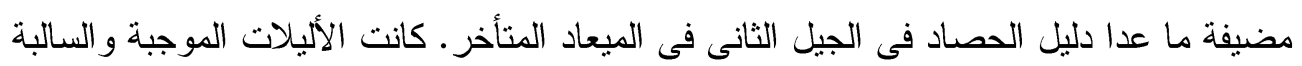
موزعة بغير انتظام بين الأباء لكل الصفات تحت ميعادى الزر اعة. كانت الأباء تحتوى على أليلات موجبة اكثر لكل الصفات فى كلا الجيلين تحت ميعادى الزر اعة ما عدا تاريخ التزهير في الجيل الأول

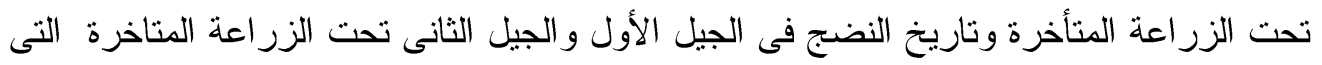

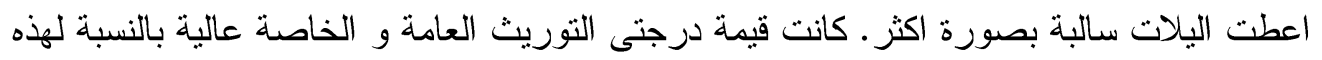
الصفات فى الاجيال الانعز الية ما عدا دليل الحصاد مما يوحى بمدى فاعلية الانتخاب فى الاجيال 